\title{
Studi Adsorpsi Logam Co(II), Cu(II), dan Ni(II) dalam Limbah Cair Buatan Menggunakan Adsorben Nanopartikel Magnetik $\mathrm{Fe}_{3} \mathrm{O}_{4}$ dan $\mathrm{ZnFe}_{2} \mathrm{O}_{4}$
}

\author{
Desiana Wuryanti dan Edi Suharyadi*
}

\begin{abstract}
Abstrak
Telah berhasil dilakukan studi adsorpsi logam $\mathrm{Co}(\mathrm{II}), \mathrm{Cu}(\mathrm{II})$, dan $\mathrm{Ni}(\mathrm{II})$ dalam limbah cair buatan menggunakan adsorben nanopartikel magnetik $\mathrm{Fe}_{3} \mathrm{O}_{4}$ dan $\mathrm{ZnFe}_{2} \mathrm{O}_{4}$. Nanopartikel $\mathrm{Fe}_{3} \mathrm{O}_{4}$ dan $\mathrm{ZnFe}_{2} \mathrm{O}_{4}$ disintesis menggunakan metode kopresipitasi. Pengaruh suhu $\left(30^{\circ} \mathrm{C}, 60^{\circ} \mathrm{C}, 90^{\circ} \mathrm{C}, 120^{\circ} \mathrm{C}\right.$, dan $\left.150^{\circ} \mathrm{C}\right)$, dan lama pengadukan $(10$ menit, 60 menit, dan 120 menit), serta perbandingan efektivitas adsorben nanopartikel $\mathrm{Fe}_{3} \mathrm{O}_{4}$ dan $\mathrm{ZnFe}_{2} \mathrm{O}_{4}$ dilakukan pada penelitian ini. Adsorpsi dalam pengaruh suhu untuk adsorben nanopartikel $\mathrm{Fe}_{3} \mathrm{O}_{4}$ menunjukkan penurunan adsorpsi. Adsorpsi maksimum terjadi pada suhu rendah $\left(300^{\circ} \mathrm{C}\right)$ dengan persentase adsorpsi logam $\mathrm{Co}(\mathrm{II}), \mathrm{Cu}(\mathrm{II})$, dan $\mathrm{Ni}(\mathrm{II})$ masing-masing sebesar 20,34\%, 88,90\%, dan 22,86\%. Pada adsorben nanopartikel $\mathrm{ZnFe}_{2} \mathrm{O}_{4}$ terjadi kenaikan adsorpsi. Adsorpsi maksimum terjadi pada suhu tertinggi $\left(150^{\circ} \mathrm{C}\right)$ dengan persentase adsorpsi logam $\mathrm{Co}(\mathrm{II}), \mathrm{Cu}(\mathrm{II})$, dan $\mathrm{Ni}$ (II) masing-masing sebesar $28,90 \%, 100 \%$, dan $29,40 \%$. Adsorpsi dalam pengaruh lama pengadukan menggunakan kedua adsorben mengalami penurunan adsorpsi. Adsorpsi logam $\mathrm{Co}(\mathrm{II}), \mathrm{Cu}(\mathrm{II})$, dan $\mathrm{Ni}(\mathrm{II})$ oleh adsorben $\mathrm{ZnFe}_{2} \mathrm{O}_{4}$ lebih efektif dibandingkan $\mathrm{Fe}_{3} \mathrm{O}_{4}$ karena memiliki ukuran butir lebih kecil.
\end{abstract}

kata kunci: adsorpsi; $\mathrm{Co}(\mathrm{II}) ; \mathrm{Cu}(\mathrm{II}) ; \mathrm{Ni}(\mathrm{II})$; adsorben

\begin{abstract}
Adsorption studies of $\mathrm{Co}(\mathrm{II}), \mathrm{Cu}(\mathrm{II})$, and $\mathrm{Ni}(\mathrm{II})$ in artificial wastewater using $\mathrm{Fe}_{3} \mathrm{O}_{4}$ and $\mathrm{ZnFe}_{2} \mathrm{O}_{4}$ magnetic nanoparticles adsorbents have been succesfully done. $\mathrm{Fe}_{3} \mathrm{O}_{4}$ and $\mathrm{ZnFe}_{2} \mathrm{O}_{4}$ nanoparticles was synthesized using coprecipitation method. The Effect of temperature $\left(30^{\circ} \mathrm{C}, 60^{\circ} \mathrm{C}, 90^{\circ} \mathrm{C}, 120^{\circ} \mathrm{C}\right.$, dan $\left.150^{\circ} \mathrm{C}\right)$, and stirring time (10 minutes, 60 minutes, and 120 minutes), and the comparative effectiveness of adsorbent $\mathrm{Fe}_{3} \mathrm{O}_{4}$ and $\mathrm{ZnFe}_{2} \mathrm{O}_{4}$ nanoparticle was performed in this study. Effect of temperature in adsorption study of $\mathrm{Fe}_{3} \mathrm{O}_{4}$ nanoparticle adsorbent have showed a decrease in adsorption with maximum adsorption occurs at low temperature $\left(30^{\circ} \mathrm{C}\right)$ with the percentage of metal adsorption $\mathrm{Co}(\mathrm{II}), \mathrm{Cu}(\mathrm{II})$, and $\mathrm{Ni}(\mathrm{II})$ was $20.34 \%, 88 \%, 90 \%$, and $22,86 \%$, respectively. The effect of temperature in adsorption study of $\mathrm{ZnFe}_{2} \mathrm{O}_{4}$ nanoparticle adsorbent have showed increase in adsorption, maximum adsorption occurs at the highest temperature $\left(150^{\circ} \mathrm{C}\right)$ with the percentage of metal adsorption $\mathrm{Co}(\mathrm{II}), \mathrm{Cu}(\mathrm{II})$ and $\mathrm{Ni}$ (II) was $28,90 \%, 100 \%$ and $29,40 \%$ respectively. While the influence of difference in stirring time at metal adsorption in both adsorbent have showed decrease in adsorption. Adsorption of $\mathrm{Co}$ (II), $\mathrm{Cu}(\mathrm{II})$, and $\mathrm{Ni}(\mathrm{II})$ on adsorbent $\mathrm{ZnFe}_{2} \mathrm{O}_{4}$ more effective than $\mathrm{Fe}_{3} \mathrm{O}_{4}$ because it has a smaller on particle sizes. Thus, the adsorbent of $\mathrm{Fe}_{3} \mathrm{O}_{4}$ and $\mathrm{ZnFe}_{2} \mathrm{O}_{4}$ magnetic nanoparticles can be used to adsorp of $\mathrm{Co}$ (II), $\mathrm{Cu}$ (II), and $\mathrm{Ni}(\mathrm{II})$.
\end{abstract}

keywords: adsorption; Co (II); Cu (II); Ni (II); adsorbents

\section{Pendahuluan}

Limbah industri sebagian besar mengandung bahan-bahan kimia berbahaya. Perhatian utama

\footnotetext{
*Korespondensi: esuharyadi@ugm.ac.id

Department of Physics, Universitas Gadjah Mada, Sekip Utara PO BOX BLS 21, 55281, Yogyakarta, Indonesia

Informasi lengkap tentang penulis dapat dilihat pada akhir artikel
}

diberikan pada bahan kimia beracun yang ditemukan di sungai, yaitu logam berat. Logam berat merupakan elemen yang tidak dapat terurai (persisten) dan dapat terakumulasi melalui rantai makanan (bioakumulasi), dengan efek jangka panjang yang merugikan pada makhluk hidup [1]. Metode adsorpsi merupakan salah satu metode yang baik digunakan untuk pemurnian 
air dari logam berat. Metode Adsorpsi adalah metode yang prosesnya sederhana, biaya relative murah dan cepat. Metode adsorpsi melibatkan pembentukan ikatan antara adsorben (zat penjerap) dan adsorbat (zat terjerap).

Adsorben yang saat ini sedang banyak dikaji oleh dikaji oleh para peneliti adalah adsorben nanopartikel magnetik. Pada partikel berukuran nano, partikel adsorben memiliki luas permukaan yang besar sehingga memiliki kapasitas yang besar untuk mengadsorpsi ion logam berat [2]. Salah satu sifat istimewa dari nanopartikel magnetik adalah sifat superparamagnetik, yakni sifat suatu material yang memiliki magnetisasi yang besar ketika diberi medan magnet eksternal. Adsorben nanopartikel magnetik yang menarik untuk diteliti adalah $\mathrm{Fe}_{3} \mathrm{O}_{4}$ dan $\mathrm{ZnFe}_{2} \mathrm{O}_{4}$.

Pada penelitian ini dilakukan adsorpsi logam $\mathrm{Co}(\mathrm{II}), \mathrm{Cu}(\mathrm{II})$, dan $\mathrm{Ni}(\mathrm{II})$ dalam limbah cair buatan. Adsorpsi dilakukan dibawah pengaruh suhu dan lama pengadukan dengan menggunakan adsorben nanopartikel magnetik $\mathrm{Fe}_{3} \mathrm{O}_{4}$ dan $\mathrm{ZnFe}_{2} \mathrm{O}_{4}$. Selain itu, membandingkan efektivitas penggunaan adsorben nanopartikel magnetik $\mathrm{Fe}_{3} \mathrm{O}_{4}$ dan $\mathrm{ZnFe}_{2} \mathrm{O}_{4}$ dalam menurunkan kadar logam $\mathrm{Co}(\mathrm{II}), \mathrm{Cu}(\mathrm{II})$, dan $\mathrm{Ni}(\mathrm{II})$ di dalam limbah cair buatan.

\section{Metode Penelitian}

\subsection{Pembuatan limbah cair buatan}

Bahan dasar untuk limbah cair buatan logam $\mathrm{Co}(\mathrm{II}), \mathrm{Cu}(\mathrm{II})$, dan $\mathrm{Ni}(\mathrm{II})$ yang digunakan $\mathrm{CoSO}_{4}$, $\mathrm{CuSO}_{4} .5 \mathrm{H}_{2} \mathrm{O}$, dan $\mathrm{NiSO}_{4} \cdot 7 \mathrm{H}_{2} \mathrm{O}$. Seluruh bahan dicampur diaduk dengan keceptan 450rpm selama 4 jam. Larutan tersebut diatur pada $\mathrm{pH} 7$, kemudian diuji AAS.

\subsection{Sintesis Nanopartikel $\mathrm{Fe}_{3} \mathrm{O}_{4}$}

Proses sintesis $\mathrm{Fe}_{3} \mathrm{O}_{4}$ dengan metode kopresipitasi dilakukan dengan bahan $\mathrm{FeSO}_{4} .7 \mathrm{H}_{2} \mathrm{O}$, dan $\mathrm{FeCl}_{3} \cdot 6 \mathrm{H}_{2} \mathrm{O}$ dan $\mathrm{NH}_{4} \mathrm{OH}$ dicampurkan. Proses sintesis dengan suhu $60^{\circ} \mathrm{C}$ selama 90 menit dan kecepatan 450 rpm. Setelah itu larutan $\mathrm{Fe}_{3} \mathrm{O}_{4}$ udian dicuci dan diendapkan kemudian dikeringkan menggunakan furnace dengan suhu $60^{\circ} \mathrm{C}$ selama 90 menit.

\subsection{Sintesis nanopartikel $\mathrm{ZnFe}_{2} \mathrm{O}_{4}$}

Proses sintesis $\mathrm{ZnFe}_{2} \mathrm{O}_{4}$ dengan metode kopresipitasi dilakukan dengan dicampurkan $1,149 \mathrm{~g} \mathrm{ZnSO} 4.7 \mathrm{H}_{2} \mathrm{O}$, $2,162 \mathrm{~g} \mathrm{FeCl}_{3} \cdot 6 \mathrm{H}_{2} \mathrm{O}$, dan $3,37 \mathrm{~mL} \mathrm{HCl}$ didalam $20 \mathrm{~mL}$ aquades. Selanjutnya, campuran tersebut dimasukkan kedalam larutan $\mathrm{NaOH} 2,99 \mathrm{~g}$ dalam $50 \mathrm{~mL}$ aquades tetes demi tetes secara perlahan dengan suhu $90^{\circ} \mathrm{C}$ selama 1 jam dan kecepatan pengadukan $1000 \mathrm{rpm}$.

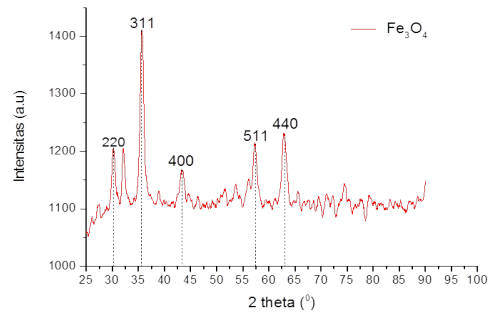

Gambar 1: Hasil karakterisasi XRD sampel $\mathrm{Fe}_{3} \mathrm{O}_{4}$

Tabel 1: Parameter Kisi dan Ukuran Partikel

\begin{tabular}{|c|c|c|c|}
\hline No & Sampel & Ukuran partikel $(\mathrm{nm})$ & Parameter kisi $(\AA)$ \\
\hline 1 & $\mathrm{Fe}_{3} \mathrm{O}_{4}$ & $(8,34 \pm 0,29)$ & $(12,10 \pm 0,10)$ \\
\hline 2 & $\mathrm{ZnFe}_{2} \mathrm{O}_{4}$ & $(8,44 \pm 0,30)$ & $(9,40 \pm 0,10)$ \\
\hline
\end{tabular}

Setelah itu, larutan dicuci dan diendapkan. Endapan magnet $\mathrm{ZnFe}_{2} \mathrm{O}_{4}$ yang sudah bersih dan tidak berbau (murni) dikeringkan di dalam furnace pada suhu $90^{\circ} \mathrm{C}$ selama 4-5 jam.

\subsection{Karakterisasi nanopartikel magnetik $\mathrm{Fe}_{3} \mathrm{O}_{4}$ dan} $\mathrm{ZnFe}_{2} \mathrm{O}_{4}$

Karakterisasi nanopartikel magnetik $\mathrm{Fe}_{3} \mathrm{O}_{4}$ dan $\mathrm{ZnFe}_{2} \mathrm{O}_{4}$ hasil sintesis menggunakan alat XRD di Laboratorium Kimia Analitik, Kimia UGM. Setelah data diperoleh kemudian diolah menggunakan software origin9 sehingga diperoleh grafik dengan puncak-puncak. Kemudian dihitung parameter kekisi dan indeks miller.

\subsection{Adsorpsi logam dalam limbah cair buatan}

Adsorpsi logam dalam limbah cair buatan dilakukan dengan dilarutkan 0,1 gram nanopartikel magnetik ke dalam $20 \mathrm{~mL}$ larutan limbah cair buatan. Kemudian diaduk dengan kecepatan 1000 rpm dengan suhu dan waktu pengadukan divariasi. Setelah proses selesai larutan diendapkan dengan magnet permanen hingga mengendap seluruhnya kemudian larutan disaring menggunakan kertas saring kemudian larutan sampel diuji menggunakan AAS.

\section{Hasil dan Pembahasan}

3.1 Karakterisasi Nanopartikel $\mathrm{Fe}_{3} \mathrm{O}_{4}$ dan $\mathrm{ZnFe}_{2} \mathrm{O}_{4}$ Menggunakan XRD

\section{Karakterisasi Sampel $\mathrm{Fe}_{3} \mathrm{O}_{4}$}

Pola difaktogram dari hasil analisa karakterisasi XRD sampel $\mathrm{Fe}_{3} \mathrm{O}_{4}$ (gambar 1) mengindikasikan bahwa telah terbentuk fasa $\mathrm{Fe}_{3} \mathrm{O}_{4}$. Hal tersebut didasarkan pada nilai parameter kekisi yang telah diestimasi pada sudut $2 \theta=35,68^{\circ}$ dengan indeks bidang (311) adalah 


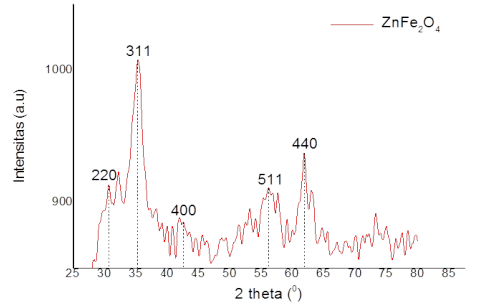

Gambar 2: Hasil karakterisasi XRD sampel $\mathrm{ZnFe}_{2} \mathrm{O}_{4}$

Tabel 2: Data kadar awal limbah buatan

\begin{tabular}{|c|c|c|}
\hline No & lon logam & Kadar logam (ppm) \\
\hline 1 & $\mathrm{Co}$ & $285 \pm 3$ \\
\hline 2 & $\mathrm{Cu}$ & $2,2 \pm 1,5$ \\
\hline 3 & $\mathrm{Ni}$ & $306 \pm 4$ \\
\hline
\end{tabular}

8,34 dengan jarak antar bidang kristal 2,51 mendekati nilai parameter kekisi $\mathrm{Fe}_{3} \mathrm{O}_{4}$ dalam keadaan bulk $(8,397)$ [3]. Selain itu, terbentuk puncak-puncak difraksi dengan indeks miller (220), (400), (511) dan (440) yang merupakan indeks khas dari struktur kubik spinel $\mathrm{Fe}_{3} \mathrm{O}_{4}$ yang selalu muncul dalam difaktogram XRD bahan $\mathrm{Fe}_{3} \mathrm{O}_{4}$ (JCPDS No.2210-12). Ukuran butir nanopartikel dihitung menggunakan persamaan scherrer diperoleh 12,1 nm. Ukuran partikel ini menunjukkan bahwa sampel $\mathrm{Fe}_{3} \mathrm{O}_{4}$ yang diperoleh berukuran nanopartikel.

Pola difaktogram dari hasil analisa karakterisasi XRD sampel $\mathrm{ZnFe}_{2} \mathrm{O}_{4}$ (gambar 2) mengindikasikan bahwa telah terbentuk fasa $\mathrm{ZnFe}_{2} \mathrm{O}_{4}$. Fasa $\mathrm{ZnFe}_{2} \mathrm{O}_{4}$ ini terindikasi dari terbentuknya puncak-puncak difraksi dengan indeks bidang (220), (311), (400), (511), dan (440) yang merupakan puncak difraksi $\mathrm{ZnFe}_{2} \mathrm{O}_{4}$ pada material bulk. Hal tersebut diperkuat dengan menganalisa salah satu puncak dengan intensitas tertinggi dengan indeks (311) diperoleh parameter kekisi 8,44 dengan jarak antar bidang kristal 2,54 sesuai dengan JCPDS No 2210-12. Menggunakan persamaan scherer diperoleh ukuran butir partikel $9,4 \mathrm{~nm}$ yang merupakan ukuran nanopartikel dari $\mathrm{ZnFe}_{2} \mathrm{O}_{4}$.

\subsection{Hasil Limbah Cair Buatan}

Pada tabel 2 menunjukkan bahwa kadar awal logam dalam limbah cair buatan memiliki perbedaan yang cukup besar. Hal tersebut dapat terjadi karena adanya pengendapan selama kenaikan $\mathrm{pH}$ menuju $\mathrm{pH}$ netral (pengaturan $\mathrm{pH}$ ). $\mathrm{pH}$ suatu larutan menunjukkan aktivitas ion hidrogen $\left(\mathrm{H}^{+}\right)$dalam larutan tersebut dan dinyatakan sebagai konsentrasi ion hidrogen (dalam mole per liter) pada suhu tertentu adanya pengendapan selama kenaikan $\mathrm{pH}$ menuju $\mathrm{pH}$ netral (pengaturan $\mathrm{pH}) . \mathrm{pH}$ suatu larutan menunjukkan aktivitas ion hidrogen $\left(\mathrm{H}^{+}\right)$dalam larutan tersebut dan dinyatakan sebagai konsentrasi ion hidrogen (dalam mole per liter) pada suhu tertentu. Endapan akan terbentuk karena ion $\left(\mathrm{H}^{+}\right)$ bergabung dengan ion logam dan membentuk endapan dengan konsentrasi ion logam dan ion $\left(\mathrm{H}^{+}\right)$saat itu lebih tinggi dari hasil kali kelarutan. Tiap logam memiliki pH spesifik saat kelarutannya minimum sehingga dapat mengendap dengan maksimal[4]. Oleh sebab itu, dapat diasumsikan bahwa $\mathrm{pH}$ spesifik untuk ion logam mengendap pada $\mathrm{Cu}^{2+}<\mathrm{Co}^{2+}<\mathrm{Ni}^{2+}$ sehingga kadar ion logam $\mathrm{Cu}^{2+}$ pada kadar yang paling sedikit.

\subsection{Pengaruh Suhu Terhadap Adsorpsi Kadar Logam} $\mathrm{Co}(\mathrm{II}), \mathrm{Cu}(\mathrm{II})$, dan Ni(II) pada Limbah Cair Buatan 3.3.1 Pengaruh suhu terhadap penurunan kadar logam $\mathrm{Co}(\mathrm{II}), \mathrm{Cu}(\mathrm{II})$, dan Ni(II) dengan adsorben $\mathrm{Fe}_{3} \mathrm{O}_{4}$

Pada penelitian ini, hasil yang ditunjukkan pada tabel 3 menunjukkan adanya adsorpsi pada ion logam $\mathrm{Co}^{2+}, \mathrm{Cu}^{2+}$, dan $\mathrm{N}^{2+}$ dengan menggunakan adsorben nanopartikel $\mathrm{Fe}_{3} \mathrm{O}_{4}$. Sebelum diberikan perlakuan peningkatan suhu atau pada suhu $30^{\circ} \mathrm{C}$ (suhu ruang) terdapat perbedaan adsorpsi antar ion logamnya. Adsorpsi ion logam $\mathrm{Cu}^{2+}>\mathrm{Ni}^{2+}>\mathrm{Co}^{2+}$, hal tersebut mungkin dikarenakan, proses adsorpsi merupakan terjadinya ikatan antara adsorben dan adsorbat. Karakteristik adsorbat diantaranya sifat kemagnetan, massa molekul, elektronegativitas, daya hantar panas, dan massa molekul sangat memengaruhi tingkat adsorpsi. Ion logam $\mathrm{Cu}^{2+}$ menunjukkan tingkat adsorpsi tertinggi dibandingkan ion logam lainnya. Hal ini mungkin karena kadar awal ion logam $\mathrm{Cu}^{2+}$ yang sangat kecil dibandingkan ion logam lainnya dengan jumlah konsentrasi adsorben yang sama sehingga ion logam $\mathrm{Cu}^{2+}$ memiliki peluang untuk teradsorpsi lebih banyak. Selain itu, bisa juga karena nilai elektronegativitas $\mathrm{Cu}^{2+}>\mathrm{Ni}^{2+}>\mathrm{Co}^{2+}$ sesuai dalam tabel periodik yang menyatakan dari kiri ke kanan nilai elektronegativitas makin tinggi. Nilai elektronegativitas ini menyatakan kecenderungan atom untuk menarik pasangan elektron ikatan sehingga ion logam dengan elektronegativitas lebih tinggi akan lebih mudah berinteraksi dengan adsorben.

Hasil yang diperoleh secara keseluruhan, seluruh ion logam cenderung mengalami penurunan persentase adsorpsi seiring dengan kenaikan suhu. Hasil tersebut diperoleh karena ketika suhu semakin tinggi, maka partikel akan bergerak aktif. Hal tersebut akan menyebabkan tumbukan antar partikel dan terjadi 
Tabel 3: Pengaruh suhu terhadap penurunan kadar logam $\mathrm{Co}(\mathrm{II}), \mathrm{Cu}(\mathrm{II})$, dan $\mathrm{Ni}(\mathrm{II})$ dengan adsorben $\mathrm{Fe}_{3} \mathrm{O}_{4}$

\begin{tabular}{|c|c|c|c|c|c|c|}
\hline \multirow{3}{*}{ Suhu $\left({ }^{\circ} C\right)$} & \multicolumn{6}{|c|}{ Logam } \\
\hline & \multicolumn{2}{|l|}{ Co } & \multicolumn{2}{|l|}{$\mathrm{Cu}$} & \multicolumn{2}{|l|}{$\mathrm{Ni}$} \\
\hline & kadar akhir (ppm ) & \% penurunan & kadar akhir (ppm) & $\%$ penurunan & kadar akhir (ppm) & $\%$ penurunan \\
\hline 30 & $227,12 \pm 4,12$ & $20,34 \pm 0,63$ & $0,20 \pm 0,01$ & $88,90 \pm 0,48$ & $236,11 \pm 4,12$ & $22,80 \pm 0,69$ \\
\hline 60 & $229,60 \pm 0,87$ & $19,45 \pm 1,17$ & $0,25 \pm 0,02$ & $88,34 \pm 0,82$ & $233,90 \pm 2,06$ & $23,60 \pm 1,59$ \\
\hline 90 & $239,00 \pm 0,00$ & $16,10 \pm 0,94$ & $0,34 \pm 0,01$ & $84,00 \pm 0,61$ & $241,00 \pm 1,84$ & $21,30 \pm 1,31$ \\
\hline 120 & $275,00 \pm 3,34$ & $3,50 \pm 1,13$ & $0,53 \pm 0,01$ & $75,50 \pm 0,25$ & $304,50 \pm 3,20$ & $0,50 \pm 2,02$ \\
\hline 150 & $273,90 \pm 1,92$ & $3,94 \pm 1,28$ & $0,54 \pm 0,01$ & $74,78 \pm 0,44$ & $311,90 \pm 13,33$ & 0 \\
\hline
\end{tabular}

Tabel 4: Pengaruh suhu terhadap adsorpsi kadar logam $\mathrm{Co}(\mathrm{II}), \mathrm{Cu}(\mathrm{II})$ dan $\mathrm{Ni}(\mathrm{II})$ dengan adsorben $\mathrm{ZnFe}_{2} \mathrm{O}_{4}$

\begin{tabular}{|c|c|c|c|c|c|c|}
\hline \multirow{3}{*}{ Suhu $\left({ }^{\circ} C\right)$} & \multicolumn{6}{|c|}{ Logam } \\
\hline & \multicolumn{2}{|l|}{ Co } & \multicolumn{2}{|c|}{$\mathrm{Cu}$} & \multicolumn{2}{|c|}{$\mathrm{Ni}$} \\
\hline & kadar akhir (ppm ) & $\%$ penurunan & kadar akhir (ppm) & $\%$ penurunan & kadar akhir (ppm) & $\%$ penurunan \\
\hline RT & $222,80 \pm 2,04$ & $21,80 \pm 1,52$ & $0,05 \pm 0,03$ & $97,70 \pm 0,02$ & $241,50 \pm 1,85$ & $21,10 \pm 1,16$ \\
\hline 60 & $228,20 \pm 3,34$ & $24,90 \pm 0,27$ & Ttd & 100 & $240,38 \pm 5,53$ & $21,50 \pm 2,05$ \\
\hline 90 & $218,30 \pm 3,34$ & $23,40 \pm 1,77$ & Ttd & 100 & $230,70 \pm 8,48$ & $24,60 \pm 3,53$ \\
\hline 120 & $211,60 \pm 3,36$ & $25,70 \pm 1,04$ & Ttd & 100 & $216,80 \pm 4,89$ & $29,20 \pm 0,73$ \\
\hline 150 & $202,70 \pm 1,92$ & $28,90 \pm 1,43$ & Ttd & 100 & $202,90 \pm 1,85$ & $29,40 \pm 1,03$ \\
\hline & & & si dibawah & $\begin{array}{l}\text { s deteksi alat } \\
\text { ppm }\end{array}$ & & \\
\hline
\end{tabular}

pemutusan rantai hidroksil akibat evaporasi yang terjadi pada air dan menyebabkan desorpsi. Desorpsi adalah pelepasan ion-ion logam yang terikat di permukaan maupun pori-pori adsorben. Selain itu, pengaruh suhu terhadap adsorpsi menunjukkan semakin rendahnya kapasitas adsorpsi, yaitu ketika suhu dinaikkan dikarenakan melemahnya energi ikat antara adsorben dan adsorbat[5].

Perbedaan adsorpsi dibawah pengaruh suhu antara ion logam $\mathrm{Co}^{2+}$ dan $\mathrm{Ni}^{2+}$ menunjukkan perbedaan yang signifikan seiring kenaikan suhu. Diketahui pada adsorpsi sebelum adanya perlakuan suhu, adsorpsi keduanya menunjukkan hasil perbedaan yang tidak signifikan. Pada kenaikan suhu adsorpsi $30^{\circ} \mathrm{C}-90^{\circ} \mathrm{C}$ ion logam $\mathrm{Ni}^{2+}$ menunjukkan tingkat adsorpsi yang lebih tinggi dibandingkan ion logam $\mathrm{Co}^{2+}$. Hal ini dapat diasumsikan karena adanya perbedaan penyerapan kalor pada ion logam $\mathrm{Ni} 2+$ yang lebih cepat dibandingkan ion logam $\mathrm{Co}^{2+}$. Oleh karena itu, dengan serapan kalor yang lebih cepat menyebabkan ion logam $\mathrm{Ni}^{2+}$ lebih cepat panas sehingga ion logam $\mathrm{Ni}^{2+}$ lebih aktif bergerak dan lebih aktif menuju situs aktif pada adsorben. Oleh karena itu adsorpsi ion logam $\mathrm{Ni}^{2+}$ lebih tinggi daripada adsorpsi ion logam $\mathrm{Co}^{2+}$. Pada suhu tinggi yakni pada suhu $90^{\circ} \mathrm{C}-150^{\circ} \mathrm{C}$ adsorpsi ion logam $\mathrm{Co}^{2+}$ lebih tinggi daripada ion logam $\mathrm{Ni}^{2+}$, hal ini diasumsikan karena serapan kalor logam $\mathrm{Ni}^{2+}$ yang lebih cepat mengakibatkan gerak ion $\mathrm{Ni}^{2+}$ lebih aktif. Partikel adsorben juga bergerak cepat ketika suhu tinggi sehingga terjadi tumbukan yang lebih kuat antarpartikel. Hal ini menyebabkan terjadinya pelepasan ikatan antara ion logam $\mathrm{Ni}^{2+}$ dari partikel adsorben.
3.3.2 Pengaruh suhu terhadap adsorpsi logam Co(II), $\mathrm{Cu}(I I)$, dan Ni(II) pada limbah cair buatan dengan adsorben $\mathrm{ZnFe}_{2} \mathrm{O}_{4}$

Hasil pengujian pengaruh suhu terhadap adsorpsiion logam $\mathrm{Co}^{2+}, \mathrm{Cu}^{2+}$, dan $\mathrm{Ni}^{2+}$ dengan adsorben $\mathrm{ZnFe}_{2} \mathrm{O}_{4}$ ditunjukkan pada tabel 4 Pada suhu $30^{\circ} \mathrm{C}$, adsorpsi menggunakan adsorben $\mathrm{ZnFe}_{2} \mathrm{O}_{4}$ telah menunjukkan adanya penurunan persentase adsorpsi pada ion-ion logam. Ion logam $\mathrm{Cu}^{2+}$, diserap tinggi dengan nilai persentase $97,70 \%$ dan lebih tinggi dari ion logam $\mathrm{Co}^{2+}$ dan $\mathrm{Ni}^{2+}$ yang nilai persentase penurunannya relatif sama dengan selisih yang tidak signifikan. Hal ini tentu saja karena ion logam $\mathrm{Cu}^{2+}$ kadarnya sangat sedikit dalam larutan sehingga persentase adsorpsi lebih besar.

Berdasarkan tabel 4 menunjukkan bahwa persentase adsorpsi ion logam tembaga $\mathrm{Cu}^{2+}$ cenderung konstan dengan adsorpsi $100 \%$, sedangkan pada ion logam $\mathrm{Cu}^{2+}$ dan $\mathrm{Ni}^{2+}$ cenderung naik sedikit atau tidak terlalu signifikan seiring kenaikan suhu adsorpsi. Hal ini mengindikasikan bahwa kenaikan suhu sangat memengaruhi tingkat adsorpsi ion logam $\mathrm{Co}^{2+}$ dan $\mathrm{Ni}^{2+}$. Akan tetapi, kenaikan suhu tidak memengaruhi pada adsorpsi ion logam $\mathrm{Cu}^{2+}$ dengan adsorben $\mathrm{ZnFe} 2 \mathrm{O} 4$. Hal tersebut tentu saja karena kadar ion logam $\mathrm{Cu}^{2+}$ yang sedikit sehingga dengan suhu yang dinaikkan membuat ion logam $\mathrm{Cu}^{2+}$ lebih aktif menuju permukaan adsorben sehingga teradsorpsi sempurna.

Adsorpsi pada ion logam $\mathrm{Co}^{2+}$ dan ion logam $\mathrm{Ni}^{2+}$ cenderung mengalami kenaikan walaupun tidak terlalu signifikan. Kenaikan tingkat adsorpsi ion logam seiringkenaikan suhu disebabkan karena penurunan pHpzc dari adsorben $\mathrm{ZnFe}_{2} \mathrm{O}_{4}$ [6]. Penurunan pHpzc tersebut disebabkan oleh peningkatan suhu. 
Penurunan pHpzc menyebabkan penambahan muatan negatif pada permukaan adsorben untuk $\mathrm{pH}$ larutan yang sama sehingga menambah gaya tarik dengan adsorbat yang bermuatan positif dan menambah kemampuan adsorben untuk menarik adsorbat. Pada $p H_{p z p}$ yang rendah tingkat adsorpsi lebih memberikan hasil yang efektif. Menurut[7] adsorpsi pada $\mathrm{pH}$ tinggi hasil adsorpsi kurang sempurna karena terbentuknya senyawa oksidasi dari ion-ion logam sehingga akan menutupi permukaan adsorben dan menghalangi proses adsorpsi.

\subsubsection{Perbedaan pengaruh suhu terhadap adsorpsi} logam $\mathrm{Co}(\mathrm{II}), \mathrm{Cu}(\mathrm{II})$ dan Ni(II) pada limbah buatan dengan adsorben $\mathrm{Fe}_{3} \mathrm{O}_{4}$ dan $\mathrm{ZnFe}_{2} \mathrm{O}_{4}$

Pada tabel 3 menunjukkan pengaruh suhu terhadap adsorpsi ion logam dengan adsorben $\mathrm{Fe}_{3} \mathrm{O}_{4}$ menunjukkan kecenderungan penurunan persentase adsorpsi, sedangkan pada tabel 4 menunjukkan pengaruh suhu terhadap adsorpsi ion logam dengan adsorben $\mathrm{ZnFe}_{2} \mathrm{O}_{4}$ yang menunjukkan kecenderungan kenaikan adsorpsi. Diketahui bahwa pengaruh suhu tinggi terhadap adsorpsi menunjukkan semakin rendahnya kapasitas adsorpsi ketika suhu dinaikkan, ini dikarenakan melemahnya energi ikat antara adsorben dan adsorbat[5]. Hal tersebut berlaku pada adsorben $\mathrm{Fe}_{3} \mathrm{O}_{4}$, akan tetapi pada adsorben $\mathrm{ZnFe}_{2} \mathrm{O}_{4}$ fenomena tersebut tidak terjadi. Kecenderungan kenaikan adsorpsi dengan menggunakan adsorben $\mathrm{ZnFe}_{2} \mathrm{O}_{4}$ terjadi karena adanya penurunan pHpzc pada permukaan adsorben seiring kenaikan suhu sehingga terjadi kenaikan adsorpsi.

\subsection{Pengaruh Lama Pengadukan Terhadap Penurunan} Kadar Co(II), Cu(II) dan Ni(II) Pada Limbah Buatan 3.4.1 Pengaruh lama pengadukan terhadap persentase penurunan logam $\mathrm{Co}(\mathrm{II}), \mathrm{Cu}(\mathrm{II})$ dan $\mathrm{Ni}(\mathrm{II})$

menggunakan adsorben $\mathrm{Fe}_{3} \mathrm{O}_{4}$

Berdasarkan tabel 5, dalam lama pengadukan 10 menit atau waktu kontak yang singkat telah menunjukkan terjadinya penurunan kadar. Hal ini dapat diasumsikan adsorpsi telah terjadi dalam waktu yang singkat dengan menggunakan adsorben $\mathrm{Fe}_{3} \mathrm{O}_{4}$. Hasil persentase penurunan ion logam $\mathrm{Cu}^{2+}>\mathrm{Co}^{2+}>\mathrm{Ni}^{2+}$. Ion logam $\mathrm{Cu}^{2+}$ menunjukkan adsorpsi tertinggi karena kadar ionnya yang kecil. Pada ion logam $\mathrm{Co}^{2+}$ lebih tinggi dari adsorpsi ion logam $\mathrm{Ni}^{2+}$ dengan nilai masing-masing 40,64\% dan $21,20 \%$, sehingga dapat diasumsikan bahwa ion logam $\mathrm{Cu}^{2+}$ lebih cepat teradsorpsi dibandingkan logam $\mathrm{Ni}^{2+}$. Hal tersebut dikarenakan sifat adsorben magnetit menunjukkan sifat feromagnetik dan ion logam $\mathrm{Co}^{2+}$ memiliki sifat yang lebih kuat dibandingkan dengan ion logam $\mathrm{Ni}^{2+}$. Sifat magnetik ini merujuk pada proses penurunan kadar logam yang melibatkan dua tahap, yaitu proses adsorpsi dan proses pengendapan hasil adsorpsi dengan bantuan medan magnet luar. Ketika proses pengendapan adsorben bertambah magnetisasinya akibat medan magnet eksternal yang diberikan sehingga adsorben dapat menarik lebih banyak ion logam yang memiliki sifat magnetik lebih kuat.

Pada ion logam $\mathrm{Co}^{2+}$ penurunan kadar logamnya cenderung turun. Pada menit ke 10 sampai menit ke 120 terjadi penurunan adsorpsi yakni 40,6\% ke $10,50 \%$. Penurunan persentase adsorpsi mungkin dikarenakan, ion logam $\mathrm{Co}^{2+}$ yang telah teradsorpsi pada menit ke 10 mengalami desorpsi pada menit selanjutnya akibat tumbukan antar partikel sehingga melepaskan jerapan adsorben pada adsorbat. Pada ion logam $\mathrm{Cu}^{2+}$ pada lama pengadukan 10 menit ke 180 menit persentase adsorpsi cenderung konstan dengan memperhatikan perhitungan ralat memerikan hasil yang besarnya relatif sama. Adanya perubahan waktu tersebut belum memberikan pengaruh yang signifikan pada adsorpsi ion logam $\mathrm{Cu}^{2+}$ dengan adsorben $\mathrm{Fe}_{3} \mathrm{O}_{4}$. Hal ini juga dikarenakan kadar ion logam $\mathrm{Cu}^{2+}$ yang sangat kecil.

Pada ion logam $\mathrm{Ni}^{2+}$, persentase penurunan kadar logamnya cenderung berfluktuasi. Pada menit 10 ke 60 mengalami kenaikan dari $21,2 \%$ ke $22,8 \%$ dan menit 60 ke 120 mengalami penurunan adsorpsi dari $22,8 \%$ ke $8,6 \%$. Kenaikan adsorpsi mungkin dikarenakan pada menit 10 ke menit 60 memberikan waktu yang lebih lama untuk ion logam $\mathrm{Ni}^{2+}$ bergerak menuju ke situs aktif pada permukaan adsorben. Ketika terjadi penurunan pada menit ke 60 mungkin dikarenakan desorpsi akibat tumbukan antar partikel yang frekuensinya menjadi lebih lama sehingga menyebabkan ion logam yang telah terjerap kemudian terlepas kembali.

\subsubsection{Pengaruh waktu pengadukan terhadap} penurunan kadar logam $\mathrm{Co}(\mathrm{II}), \mathrm{Cu}(\mathrm{II})$, dan $\mathrm{Ni}(\mathrm{II})$ pada limbah cair buatan dengan adsorbent $\mathrm{ZnFe}_{2} \mathrm{O}_{4}$ Pengaruh lama pengadukan terhadap peunurunan kadar ion logam $\mathrm{Co}^{2+}, \mathrm{Cu}^{2+}$, dan $\mathrm{Ni}^{2+}$ menggunakan adsorben $\mathrm{ZnFe}_{2} \mathrm{O}_{4}$ ditunjukkan pada tabel 6 Ion logam telah teradsorpsi dengan baik dalam waktu singkat. Pada penelitan [8] diketahui bahwa adsorpsi maksimal pada adsorben $\mathrm{ZnFe}_{2} \mathrm{O}_{4}$ terjadi dalam waktu 10 menit. Adsorpsi tertinggi pada ion logam $\mathrm{Cu}^{2+}$, kemudian ion logam $\mathrm{Ni}^{2+}$, dan paling rendah ion logam $\mathrm{Co}^{2+}$. Perbedaan tingkat adsorpsi ini mungkin karena bentuk adsorpsi ion logam $\mathrm{Cu}^{2+}>\mathrm{C}^{2+}>\mathrm{Ni}^{2+}$ pada adsorben nanopartikel $\mathrm{ZnFe}_{2} \mathrm{O}_{4}$ adalah Multilayer[6]. Ion-ion logam berkompetisi untuk 
Tabel 5: Pengaruh lama pengadukan terhadap penurunan kadar logam $\mathrm{Co}(\mathrm{II}), \mathrm{Cu}(\mathrm{II})$, dan $\mathrm{Ni}(\mathrm{II})$ dengan adsorben $\mathrm{Fe}_{3} \mathrm{O}_{4}$

\begin{tabular}{|c|c|c|c|c|c|c|}
\hline \multirow{3}{*}{$\begin{array}{l}\text { Waktu } \\
\text { (menit) } \\
\text { (menit) }\end{array}$} & \multicolumn{6}{|c|}{ Logam } \\
\hline & \multicolumn{2}{|l|}{$\mathrm{Co}$} & \multicolumn{2}{|c|}{$\mathrm{Cu}$} & \multicolumn{2}{|c|}{$\mathrm{Ni}$} \\
\hline & kadar akhir (ppm ) & $\%$ penurunan & kadar akhir (ppm) & $\%$ penurunan & kadar akhir (ppm) & $\%$ penurunan \\
\hline 10 & $169,20 \pm 1,32$ & $40,64 \pm 0,20$ & $0,23 \pm 0,01$ & $89,10 \pm 0,60$ & $241,00 \pm 2,04$ & $21,20 \pm 0,539$ \\
\hline 60 & $227,10 \pm 4,02$ & $20,30 \pm 0,63$ & $0,24 \pm 0,01$ & $88,90 \pm 0,485$ & $236,10 \pm 4,12$ & $22,80 \pm 0,69$ \\
\hline 120 & $255,00 \pm 3,34$ & $10,50 \pm 1,09$ & $0,21 \pm 0,01$ & $90,00 \pm 0,41$ & $279,90 \pm 4,89$ & $8,60 \pm 2,25$ \\
\hline
\end{tabular}

Tabel 6: Pengaruh lama pengadukan terhadap penurunan kadar logam logam $\mathrm{Co}(\mathrm{II}), \mathrm{Cu}(\mathrm{II})$, dan $\mathrm{Ni}$ (II) dengan adsorben $\mathrm{ZnFe}_{2} \mathrm{O}_{4}$

\begin{tabular}{|c|c|c|c|c|c|c|}
\hline \multirow{2}{*}{$\begin{array}{c}\text { Waktu } \\
\text { pengadukan } \\
\text { (menit) }\end{array}$} & \multicolumn{2}{|c|}{ Co } & \multicolumn{2}{c|}{ Logam } \\
\cline { 2 - 7 } & kadar akhir $(\mathrm{ppm})$ & $\%$ penurunan & kadar akhir $(\mathrm{ppm})$ & $\%$ penurunan & kadar akhir (ppm) & $\%$ penurunan \\
\hline 10 & $158,20 \pm 0,76$ & $44,50 \pm 0,41$ & $0,05 \pm 0,03$ & $97,60 \pm 0,39$ & $154,40 \pm 3,55$ & $49,60 \pm 1,82$ \\
\hline 60 & $222,75 \pm 2,04$ & $21,80 \pm 1,52$ & $0,05 \pm 0,03$ & $97,70 \pm 0,02$ & $241,40 \pm 1,85$ & $21,10 \pm 1,17$ \\
\hline 120 & $233,80 \pm 1,93$ & $17,90 \pm 1,14$ & $0,55 \pm 0,38$ & $74,40 \pm 0,67$ & $243,60 \pm 0,00$ & $20,40 \pm 1,02$ \\
\hline
\end{tabular}

menempati layer terdalam pada adsorben. Dengan elektronegativitas $\mathrm{Cu}^{2+}>\mathrm{Co}^{2+}>\mathrm{Ni}^{2+}$ memungkinkan dengan elektronegativitas lebih tinggi akan lebih mudah berinteraksi dengan adsorben dan menempatkan adsorben pada layer lebih dalam. Ion logam yang berada pada layer lebih luar akan lebih mudah terjadi perubahan efisiensi adsorpsi. Pada keseluruhan hasil menunjukkan bahwa persentase penurunan kadar logam mengalami fluktuasi seiring dengan bertambahnya lama pengadukan.

Adsorpsi ion logam $\mathrm{Co}^{2+}$ dan $\mathrm{Ni}^{2+}$ mengalami fluktuasi dengan lama pengadukan yang sama. Hal tersebut mungkin karena sifat ion logam $\mathrm{Co}^{2+}$ dan $\mathrm{Ni}^{2+}$ hampir sama dari segi kemagnetan bahan, yakni bersifat feromagnetik yang berpengaruh pada proses pengendapan hasil adsorpsi. Adsorpsi mengalami penurunan dari menit ke 10 ke menit 120 dengan nilai masing-masing $44,50 \%$ dan $49,60 \%$ menurun ke $17,90 \%$ dan $20,40 \%$. Hal tersebut diasumsikan bahwa penurunan persentase adsorpsi ini disebabkan oleh adanya lama pengadukan yang meningkat. Lamanya pengadukan mengakibatkan desorpsi. Hal tersebut memperkuat pernyataan bahwa adsorpsi menggunakan adsorben $\mathrm{ZnFe}_{2} \mathrm{O}_{4}$ terjadi dalam waktu singkat yakni 10 menit[8].

Adsorpsi ion logam $\mathrm{Cu}^{2+}$ mengalami fluktuasi, yaitu terjadi penurunan adsorpsi pada menit ke $10 \mathrm{ke}$ menit 120 dari $97,06 \%$ ke $74,04 \%$ dan mengalami kenaikan adsorpsi dari menit 120 ke 180 yakni $74,40 \%$ ke 96,8\% Adanya penurunan adsorpsi dari menit 10 ke menit 120 dikarenakan adsorpsi telah mencapai equilibrium time. Dengan demikian, semakin lama waktu kontak maka frekuensi tumbukan antar partikel akan meningkat dan adsorben telah jenuh sehingga terjadi desorpsi yang menurunkan kapasitas adsorpsi.
3.4.3 Perbedaan pengaruh lama pengadukan terhadap adsorpsi logam $\mathrm{Co}(\mathrm{II}), \mathrm{Cu}(\mathrm{II})$ dan Ni(II) pada limbah cair buatan dengan adsorben $\mathrm{Fe}_{3} \mathrm{O}_{4}$ dan $\mathrm{ZnFe}_{2} \mathrm{O}_{4}$

Adsorpsi dengan adsorben nanopartikel $\mathrm{Fe}_{3} \mathrm{O}_{4}$ dan adsorben $\mathrm{ZnFe}_{2} \mathrm{O}_{4}$ keseluruhan menunjukkan penurunan adsorpsi. Hal ini diasumsikan adsorpsi menggunakan kedua adsorben seiring bertambahnya waktu kontak akan mengakibatkan desorpsi karena diasumsikan adsorben $\mathrm{Fe}_{3} \mathrm{O}_{4}$ dan adsorben $\mathrm{ZnFe}_{2} \mathrm{O}_{4}$ menjerap ion logam dalam waktu yang singkat. Oleh karena itu, dengan frekuensi tumbukan yang lama maka adsorpsi menurun.

\subsection{Perbandingan Efektivitas Adsorpsi Adsorben $\mathrm{Fe}_{3} \mathrm{O}_{4}$ dan $\mathrm{ZnFe}_{2} \mathrm{O}_{4}$}

3.5.1 Variasi adsorben $\mathrm{Fe}_{3} \mathrm{O}_{4}$ dan $\mathrm{ZnFe}_{2} \mathrm{O}_{4}$ pada suhu RT dan lama pengadukan 10 menit

Tabel 7 menunjukkan perbandingan Adsorpsi $\mathrm{Fe}_{3} \mathrm{O}_{4}$ dan $\mathrm{ZnFe}_{2} \mathrm{O}_{4}$ pada waktu pengadukan 10 menit dan suhu RT. Pada adsorpsi ion logam $\mathrm{Cu}^{2+}$ menunjukkan hasil adsorpsi yang tinggi dengan menggunakan adsorben $\mathrm{ZnFe}_{2} \mathrm{O}_{4}$ dibandingkan dengan adsorben $\mathrm{Fe}_{3} \mathrm{O}_{4}$. Nilai persentase penurunan kadar ion logam menggunakan adsorben $\mathrm{Fe}_{3} \mathrm{O}_{4}$ sebesar 97,60\% dan adsorben $\mathrm{Fe}_{3} \mathrm{O}_{4}$ sebesar 89,10\%. Hasil tersebut menunjukkan bahwa ion logam $\mathrm{Cu}^{2+}$ berinteraksi lebih baik dengan adsorben $\mathrm{ZnFe}_{2} \mathrm{O}_{4}$ dibandingkan dengan adsorben $\mathrm{Fe}_{3} \mathrm{O}_{4}$.

Ion logam $\mathrm{Co}^{2+}$ teradsorpsi dengan adsorben $\mathrm{ZnFe}_{2} \mathrm{O}_{4}$ lebih efektif, mungkin karena reaksi adsorpsi antara ion logam $\mathrm{Co}^{2+}$ dan $\mathrm{ZnFe}_{2} \mathrm{O}_{4}$ lebih cepat terjadi dibandingkan dengan adsorben $\mathrm{Fe}_{3} \mathrm{O}_{4}$. Begitu pula dengan adsorpsi logam $\mathrm{Ni}^{2+}$ Pada adsorpsi ion logam $\mathrm{Ni}^{2+}$ adsorpsi dengan menggunakan adsorben $\mathrm{Fe}_{3} \mathrm{O}_{4}$ dan $\mathrm{ZnFe}_{2} \mathrm{O}_{4}$ menunjukkan persentase penurunan masing-masing $21,2 \%$ dan $49,6 \%$. Hasil ini menunjukkan bahwa adsorben $\mathrm{ZnFe}_{2} \mathrm{O}_{4}$ lebih efektif 
Tabel 7: Perbandingan adsorpsi $\mathrm{Fe}_{3} \mathrm{O}_{4}$ dan $\mathrm{ZnFe}_{2} \mathrm{O}_{4}$ pada suhu $60^{\circ}$ dan waktu pengadukan 60 menit

\begin{tabular}{|c|c|c|c|c|c|}
\hline \multirow{2}{*}{ Logam } & \multirow{2}{*}{ Kadar Awal } & \multicolumn{4}{|c|}{ Adsorben } \\
\cline { 3 - 6 } & & \multicolumn{2}{|c|}{$\mathrm{Fe}_{3} \mathrm{O}_{4}$} & \multicolumn{2}{c|}{$\mathrm{ZnFe}_{2} \mathrm{O}_{4}$} \\
\cline { 3 - 6 } & & kadar akhir $(\mathrm{ppm})$ & $\%$ penurunan & kadar akhir $(\mathrm{ppm})$ & $\%$ penurunan \\
\hline $\mathrm{Cu}$ & 2,15 & $0,23 \pm 0,01$ & $89,10 \pm 0,60$ & $0,05 \pm 0,03$ & $97,60 \pm 0,39$ \\
\hline $\mathrm{Co}$ & 285,13 & $169,20 \pm 1,32$ & $40,60 \pm 0,20$ & $158,20 \pm 0,76$ & $44,50 \pm 0,41$ \\
\hline $\mathrm{Ni}$ & 306,11 & $241,00 \pm 2,04$ & $21,20 \pm 0,54$ & $154,40 \pm 3,55$ & $49,60 \pm 1,82$ \\
\hline
\end{tabular}

Tabel 8: Perbandingan adsorpsi $\mathrm{Fe}_{3} \mathrm{O}_{4}$ dan $\mathrm{ZnFe}_{2} \mathrm{O}_{4}$ pada waktu pengadukan 10 menit dan suhu $\mathrm{RT}$

\begin{tabular}{|c|c|c|c|c|c|}
\hline \multirow{2}{*}{ Logam } & \multirow{2}{*}{ Kadar Awal } & \multicolumn{4}{|c|}{ Adsorben } \\
\cline { 3 - 6 } & & \multicolumn{2}{|c|}{$\mathrm{Fe}_{3} \mathrm{O}_{4}$} & \multicolumn{2}{c|}{$\mathrm{ZnFe}_{2} \mathrm{O}_{4}$} \\
\cline { 3 - 6 } & & kadar akhir $(\mathrm{ppm})$ & $\%$ penurunan & kadar akhir (ppm) & \% penurunan \\
\hline $\mathrm{Cu}$ & 2,15 & $0,25 \pm 0,02$ & $88,30 \pm 0,82$ & Ttd & 100 \\
\hline $\mathrm{Co}$ & 285,13 & $229,60 \pm 0,88$ & $19,50 \pm 1,17$ & $228,20 \pm 3,34$ & $24,90 \pm 0,27$ \\
\hline $\mathrm{Ni}$ & 306,11 & $233,90 \pm 2,06$ & $23,60 \pm 1,59$ & $240,38 \pm 5,53$ & $21,50 \pm 2,05$ \\
\hline
\end{tabular}

dibandingkan adsorben $\mathrm{Fe}_{3} \mathrm{O}_{4}$ dalam mengadsorpsi ion logam $\mathrm{Ni}^{2+}$.

Hasil yang ditunjukkan pada tabel 7 dan tabel 8, secara keseluruhan adsorben $\mathrm{ZnFe}_{2} \mathrm{O}_{4}$ memiliki efektivitas adsorpsi yang lebih tinggi daripada adsorben $\mathrm{Fe}_{3} \mathrm{O}_{4}$. Hal ini diasumsikan karena adsorben $\mathrm{ZnFe}_{2} \mathrm{O}_{4}$ lebih reaktif daripada adsorben $\mathrm{Fe}_{3} \mathrm{O}_{4}$ yang ditinjau dari perbedaan ukuran partikel adsorben. Berdasarkan hasil analisa XRD menunjukkan bahwa ukuran nanopartikel $\mathrm{ZnFe}_{2} \mathrm{O}_{4}$, yakni 9,4 nm dan lebih kecil dibandingkan ukuran nanopartikel $\mathrm{Fe}_{3} \mathrm{O}_{4}$ yang memiliki ukuran 12,1 nm. Hal tersebut membuat nanopartikel $\mathrm{ZnFe}_{2} \mathrm{O}_{4}$ akan lebih banyak memliki situs aktif untuk mengikat ion adsorbat sehingga akan lebih efektif adsorpsinya. Selain itu, dengan ukuran partikel yang lebih kecil menyebabkan luas permukaan menjadi lebih besar sehingga akan memungkinkan adsorben untuk memberikan luas permukaan adsorpsi lebih besar pada adsorbat yang akan teradsorpsi. Dengan demikian, efektivitas adsorpsi akan lebih tinggi dari luas permukaan adsorben yang lebih sempit.

\subsubsection{Variasi adsorben $\mathrm{Fe}_{3} \mathrm{O}_{4}$ dan $\mathrm{ZnFe}_{2} \mathrm{O}_{4}$ pada suhu $60^{\circ}$ dan waktu pengadukan 60 menit} Variasi adsorben $\mathrm{Fe}_{3} \mathrm{O}_{4}$ dan $\mathrm{ZnFe}_{2} \mathrm{O}_{4}$ pada suhu $60^{\circ}$ dan waktu pengadukan 60 menit menunjukkan bahwa adsorpsi ion logam $\mathrm{Co}^{2+}$ dan $\mathrm{Cu}^{2+}$ dengan adsorben $\mathrm{ZnFe}_{2} \mathrm{O}_{4}$ lebih tinggi dibandingkan adsorpsi dengan menggunakan adsorben $\mathrm{Fe}_{3} \mathrm{O}_{4}$. Nilai persentase penurunan menggunakan adsorben $\mathrm{Fe}_{3} \mathrm{O}_{4}$ dan adsorben $\mathrm{ZnFe}_{2} \mathrm{O}_{4}$ pada ion logam $\mathrm{Cu}^{2+}$ secara berturut-turut $88,30 \%$ dan $100 \%$. Pada ion logam $\mathrm{Co}^{2+}$ nilai persentase penurunan menggunakan adsorben $\mathrm{Fe}_{3} \mathrm{O}_{4}$ dan adsorben $\mathrm{ZnFe}_{2} \mathrm{O}_{4}$ secara berturut-turut teradsorpsi dengan adsorben $\mathrm{ZnFe}_{2} \mathrm{O}_{4}$ 19,5\% dan 24,9\%. Pada ion logam $\mathrm{Ni}^{2+}$ adsorben $\mathrm{Fe}_{3} \mathrm{O}_{4}$ lebih efektif dibandingkan dengan menggunakan adsorben $\mathrm{ZnFe}_{2} \mathrm{O}_{4}$ dengan nilai persentase $23,6 \%>21,5 \%$.
Pada adsorpsi ion logam $\mathrm{Cu}^{2+}$ mencapai adsorpsi maksimal dengan adsorben $\mathrm{ZnFe}_{2} \mathrm{O}_{4}$. Hal ini menunjukkan bahwa ion logam $\mathrm{Cu}_{2+}$ teradsorpsi secara efektif dengan adsorben $\mathrm{ZnFe}_{2} \mathrm{O}_{4}$ sehingga terjadi equilibrium adsorption. Equilibrium adsorption merupakan kesetimbangan adsorpsi karena ion logam $\mathrm{Cu}^{2+}$ telah menempati seluruh permukaan adsorben pada keadaan dengan suhu dan lama pengadukan tersebut. Pada ion logam $\mathrm{Co}^{2+}$ adsorpsi juga lebih efektif menggunakan adsorben $\mathrm{ZnFe}_{2} \mathrm{O}_{4}$. Hal tersebut menguatkan bahwa ukuran butir adsorben $\mathrm{ZnFe}_{2} \mathrm{O}_{4}$ yang lebih kecil daripada $\mathrm{Fe}_{3} \mathrm{O}_{4}$ sangat memengaruhi aktivitas adsorpsi.

Pada adsorpsi ion logam $\mathrm{Ni}^{2+}$ menunjukkan bahwa tingkat adsorpsi lebih baik dengan menggunakan adsorben $\mathrm{Fe}_{3} \mathrm{O}_{4}$ daripada adsorben $\mathrm{ZnFe}_{2} \mathrm{O}_{4}$ hal ini berbeda pada hasil tabel 7 yang menunjukkan bahwa adsorben $\mathrm{ZnFe}_{2} \mathrm{O}_{4}$ lebih efektif dibandingkan adsorben $\mathrm{Fe}_{3} \mathrm{O}_{4}$. Akan tetapi, nilai adsorpsi yang menunjukkan adsorben $\mathrm{Fe}_{3} \mathrm{O}_{4}$ lebih efektif dibandingkan adsorpsi dengan $\mathrm{ZnFe}_{2} \mathrm{O}_{4}$ menunjukkan selisih yang tidak signifikan dengan nilai masing-masing 23,60\%>21,50\%. Pada hasil tabel 7 selisih adsorpsi kedua adsorben lebih signifikan dengan selisih $28,4 \%$. Pada variasi adsorben tabel 8 dapat dinyatakan bahwa suhu dan lama pengadukan lebih tinggi daripada variasi adsorben pada tabel 7. Hal ini mengindikasikan bahwa suhu dan lama pengadukan ikut berpengaruh pada tingkat adsorpsi. Dari keterangan tersebut diasumsikan bahwa adsorben $\mathrm{Fe}_{3} \mathrm{O}_{4}$ membutuhkan suhu dan lama pengadukan yang lebih tinggi dalam menjerap ion logam $\mathrm{Ni}^{2+}$. Tetapi, semakin tinggi suhu dan lama pengadukan menyebabkan adsorben $\mathrm{ZnFe}_{2} \mathrm{O}_{4}$ menurun tingkat adsorpsinya. Hal ini diasumsikan terjadi kerusakan struktur pada $\mathrm{ZnFe}_{2} \mathrm{O}_{4}$ pada suhu dan lama pengadukan yang lebih tinggi sehingga menurunkan kapasitas adsorpsi. 


\section{Kesimpulan}

Berdasarkan penelitian yang telah dilaksanakan dengan hasil yang telah diperoleh maka dapat dsimpulkan sebagai berikut:

1) Hasil studi adsorpsi menunjukkan bahwa suhu sangat memengaruhi adsorpsi. Pada adsorpsi dengan adsorben nanopartikel $\mathrm{Fe}_{3} \mathrm{O}_{4}$ menunjukkan adanya penurunan adsorpsi seiring dengan kenaikan suhu sedangkan pada adsorben nanopartikel $\mathrm{ZnFe}_{2} \mathrm{O}_{4}$ menunjukkan adanya kenaikan adsorpsi seiring dengan kenaikan suhu.

2) Lama pengadukan sangat berpengaruh pada proses adsorpsi. Pada adsorpsi logam $\mathrm{Co}(\mathrm{II}), \mathrm{Cu}(\mathrm{II})$, dan $\mathrm{Ni}(\mathrm{II})$ dengan adsorben $\mathrm{Fe}_{3} \mathrm{O}_{4}$ dan $\mathrm{ZnFe}_{2} \mathrm{O}_{4}$ cenderung menunjukkan penurunan adsorpsi. Adsorpsi menggunakan adsorben $\mathrm{Fe}_{3} \mathrm{O}_{4}$ dan $\mathrm{ZnFe}_{2} \mathrm{O}_{4}$ berlangsung dalam waktu yang singkat.

3) Hasil studi adsorpsi menunjukkan bahwa adsorben nanopartikel $\mathrm{ZnFe}_{2} \mathrm{O}_{4}$ lebih efektif digunakan dibandingkan adsorben nanopartikel $\mathrm{Fe}_{3} \mathrm{O}_{4}$ karena nanopartikel $\mathrm{ZnFe}_{2} \mathrm{O}_{4}$ memiliki ukuran butir yang lebih kecil dibandingkan ukuran nanopartikel $\mathrm{Fe}_{3} \mathrm{O}_{4}$.

\section{Ucapan Terima Kasih}

Penulis mengucapkan terimakasih kepada Dr. Fahrudin Nugroho selaku ketua Prodi Fisika dan Dr. Mitrayana selaku Ketua Jurusan Fisika yang telah memberikan ijin penelitian ini. Penulis juga mengucapkan terimakasih kepada Dr. Mirza Satriawan dan Dr. Iman Santosa yang telah membantu memberikan saran dalam penelitian ini.

\section{Pustaka}

1. Terangna: Water Pollution, the Course of the Environment Impact Assesments. Institute of Ecology : Padjajaran University, Bandung (1991)

2. Palanisamy, K.L., Devabharathi, V., Sundaram, M.: The utility of magnetite iron oxide nanoparticles stabilized by carrier oils in removal of heavy metals from waste water. Journal Applied Natural and science vol.1, 2321-8851 (2013)

3. Coey, J.M.D.: Magnetism and Magnetic Materials. Cambridge University Press, United States of America (2009)

4. Hakim, L., Supriyatna, Y.I.: Pengambilan Logam Ni Dalam Limbah Elektroplating Dengan Proses Koagulasi Dan Flokulasi. Universitas Diponegoro, Semarang (2009)

5. Zhao, L., Li, X., Zhao, X., Qu, Z., Yuan, D., Hu, X., Chen, G.: Synthesis, characterization and adsorptive performance of $\mathrm{mgfe}_{2} \mathrm{O}_{4}$ nanosphere for $\mathrm{SO}_{2}$ removal, Journal of Hazardous Materials vol. 184, 704-709 (2010)

6. Putri, T.E.: Studi adsorpsi logam tembaga (cu), besi (fe), dan nikel (ni) dalam limbah cair buatan menggunakan adsorben nanopartikel magnetik magnesium ferrite $\left(\mathrm{mgfe}_{2} \mathrm{O}_{4}\right)$. PhD thesis, Yogyakarta, Universitas Gadjah Mada (2015)

7. Sukardjo: Kimia Anorganik. Rineka Cipta, Jakarta (1990)

8. Jia, Z., Qin, Q., Liu, J., Zhang, X., hu, R., Li, S., Zu, R.: The suntesis of hierarchial zinferit architecture and their application for $\mathrm{cr}(\mathrm{vi})$ adsorption removal from aqeous solution. Journal Superlatices and Microstructures (2007) 